\title{
Detection and Differentiation of Phaeoisariopsis griseola Isolates with the Polymerase Chain Reaction and Group-Specific Primers
}

\author{
P. Guzmán, Department of Plant Pathology, P. Gepts and S. Temple, Department of Agronomy and Range \\ Science, University of California, Davis; A. B. C. Mkandawire, Bunda College of Agriculture, Lilongwe, Malawi; \\ and R. L. Gilbertson, Department of Plant Pathology, University of California, Davis 95616
}

\begin{abstract}
Guzmán, P., Gepts, P., Temple, S., Mkandawire, A. B. C., and Gilbertson, R. L. 1999. Detection and differentiation of Phaeoisariopsis griseola isolates with the polymerase chain reaction and group-specific primers. Plant Dis. 83:37-42.

Specific detection of the two major groups of Phaeoisariopsis griseola (Andean and Mesoamerican) from infected common bean (Phaseolus vulgaris) leaves was achieved by amplification of different-sized DNA fragments with polymerase chain reaction (PCR) using group-specific primer pairs. These primer pairs were designed based on DNA sequences of cloned random amplified polymorphic DNA (RAPD) fragments. Using this method, P. griseola isolates from diverse geographical regions (five countries) were differentiated into the two previously established groups. Various sources of fungal tissue and DNA extraction methods were tested in order to develop a rapid PCR-based method to detect and differentiate P. griseola isolates. A simple and rapid sonication method was developed that allowed for PCR detection of $P$. griseola from mycelia or synnemata and conidia collected from angular leaf spot lesions on bean leaves.
\end{abstract}

Angular leaf spot (ALS) disease of common bean (Phaseolus vulgaris L.) is caused by the imperfect fungus Phaeoisariopsis griseola (Sacc.) Ferraris. ALS is an important disease in tropical and subtropical countries and can cause severe bean yield losses (approximately 40 to $80 \%$ ) under favorable environmental conditions $(5,7,19,20)$

Breeding for disease resistance is the most practical approach for ALS disease management $(16,22)$, but the development of resistant varieties has been complicated by genetic variability of $P$. griseola. $P$. griseola genetic diversity has been examined using differential bean cultivars (1), isozyme analysis (6), and more recently, random amplified polymorphic DNA (RAPD) markers $(11,17)$. A significant finding revealed by these studies has been the identification of two major groups of $P$. griseola isolates, Andean and Mesoamerican, which appear to have coevolved with the Andean and Mesoamerican common bean gene pools, respectively (11). A practical consequence of this host-pathogen coevolution is that beans of a given gene pool were more resistant to $P$. griseola isolates that were isolated from beans of the other gene pool; i.e., Mesoamerican beans were more resistant to Andean $P$.

Corresponding author: R. L. Gilbertson

E-mail: rlgilbertson@ucdavis.edu

Accepted for publication 24 September 1998.

Publication no. D-1998-1102-01R

(C) 1999 The American Phytopathological Society griseola isolates and vice versa. This has led to the suggestion of incorporating this resistance into susceptible bean genotypes cultivated in regions with coevolved (highly pathogenic) $P$. griseola isolates. Such a strategy requires a thorough understanding of the population structure of $P$. griseola in a given region. However, Andean and Mesoamerican $P$. griseola isolates cannot be differentiated based on symptoms or morphology. A technique that could be used to rapidly characterize the $P$. griseola population in a particular area would provide important information for ALS management and for breeding for ALS disease resistance.

The polymerase chain reaction (PCR) and RAPD analysis $(23,25)$ are molecular techniques that are becoming widely used for the rapid detection and characterization of many plant pathogens $(2,4,8,11-15,18)$. This method has been used to differentiate morphologically similar isolates of Fusarium solani f. sp. cucurbitae races 1 and 2 (8), and to differentiate Gaeumannomyces graminis var. avenae from other ectotrophic root-infecting fungi associated with turfgrass diseases (24). In this study, $P$. griseola group-specific primers were developed and used in the PCR to detect and differentiate $P$. griseola isolates from different bean growing regions. A simple and rapid method of DNA extraction, based upon sonication of fungal tissues, was developed to facilitate PCR detection of $P$. griseola.

\section{MATERIAL AND METHODS}

Fungal isolates and production of mycelium. $P$. griseola isolates were obtained from individual plants with ALS symptoms collected from bean growing regions of Argentina, Brazil, Costa Rica, Malawi, and the United States. Some of these isolates have been previously described (11). Monosporic cultures were prepared for each isolate by transferring individual conidia from sporulating lesions onto V8 juice agar media and incubating plates at $25^{\circ} \mathrm{C}$.

To produce mycelium for total fungal genomic DNA extraction, Erlenmeyer flasks containing $100 \mathrm{ml}$ of liquid V8 media were inoculated with three agar plugs from 10-day-old cultures. These liquid cultures were placed on a shaker (150 $\mathrm{rpm}$ ), incubated for 10 to 12 days at $25^{\circ} \mathrm{C}$, and mycelium was harvested and lyophilized as previously described (11).

Inoculation of bean plants with $\boldsymbol{P}$. griseola. Two $P$. griseola isolates from Malawi (PgMal 4, Mesoamerican P. griseola group; and PgMal 38, Andean P. griseola group) were inoculated separately or together as mixed inoculum onto various bean genotypes representing the two common bean gene pools (21) (cv. Topcrop and Malawian line 12-4, Andean gene pool; cv. Sutter Pink and Malawian line Namajengo, Mesoamerican gene pool) in a greenhouse. Inoculum production and the inoculation procedure were previously described (11). When the isolates were used separately, the inoculum concentration was $2.4 \times 10^{4}$ conidia per $\mathrm{ml}$. The concentration of each isolate was $1.2 \times 10^{4}$ conidia per $\mathrm{ml}$ in the mixed inoculum. The plants were allowed to develop ALS symptoms, and then $P$. griseola from individual lesions was typed with PCR and the group-specific primer pairs. Template DNA was prepared by the sonication method (described below) from (i) mycelia from fungal colonies obtained by culturing synnemata with conidia from individual lesions on V8 media or (ii) synnemata and conidia collected from these same sporulating lesions (described below).

DNA isolation. Total fungal genomic DNA was extracted from lyophilized mycelia as previously described (11). A smallscale total genomic DNA extraction method was used for individual ALS lesions excised from infected leaves. A single lesion (approximately 0.5 to $1 \mathrm{mg}$ ) was ground in liquid nitrogen in a $1.5-\mathrm{ml} \mathrm{Ep}-$ pendorf microfuge tube with a pestle (Kontes, Fisher Scientific, Pittsburgh, PA). 
Five hundred microliters of extraction buffer $(0.5 \mathrm{M} \mathrm{NaCl}, 10 \mathrm{mM}$ Tris- $\mathrm{HCl}, \mathrm{pH}$ 7.5, $10 \mathrm{mM}$ EDTA, $1 \%$ sodium dodecyl sulfate [SDS]) was added, the tissue was ground again, and then $500 \mu \mathrm{l}$ of phenol:chloroform (1:1) was added. The tubes were vortexed for $1 \mathrm{~min}$ and centrifuged at $14,000 \mathrm{rpm}(16,000 \times g)$ for $5 \mathrm{~min}$. The aqueous phase was collected and added to $500 \mu \mathrm{l}$ of chloroform in a new Eppendorf tube. The tubes were vortexed for $1 \mathrm{~min}$ and centrifuged at $14,000 \mathrm{rpm}(16,000 \times g)$ for $5 \mathrm{~min}$. The aqueous phase was collected, and total nucleic acids were precipitated by the addition of 0.1 volume of 3 $\mathrm{M}$ sodium acetate ( $\mathrm{pH}$ 5.5) and two volumes of $100 \%$ ethanol. Total nucleic acids were recovered by centrifugation at 14,000 $\operatorname{rpm}(16,000 \times g)$ for $5 \mathrm{~min}$. The pellet was washed with $70 \%$ ethanol and resuspended in $30 \mu$ of Tris-EDTA (TE) buffer $(10 \mathrm{mM}$ Tris-HCl, pH 7.5, 1 mM EDTA).

\section{$\begin{array}{llllllllllll}1 & 2 & 3 & 4 & 5 & 6 & 7 & 8 & 9 & 10 & 11 & 12\end{array}$}

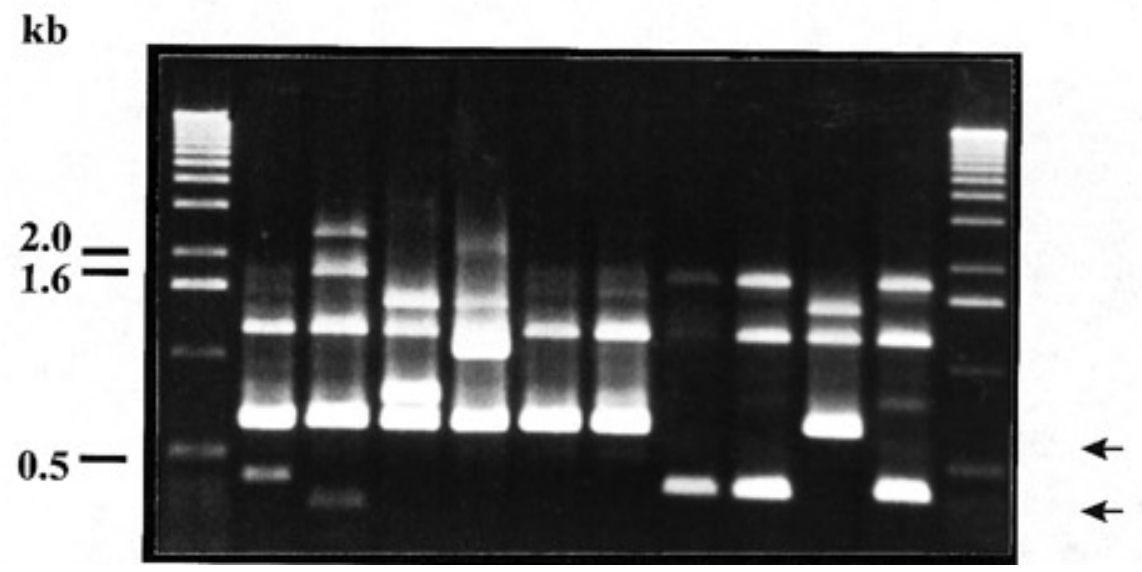

Fig. 1. Random amplified polymorphic DNA (RAPD) patterns obtained with primer OA11 from Operon Kit A for 10 isolates of Phaeoisariopsis griseola from five countries. Lanes 2 through 7 and 10 are Mesoamerican isolates (PgAr 1 and $\mathrm{PgAr} 3$ from Argentina, $\mathrm{PgCr} 1$ and $\mathrm{PgCr} 2$ from Costa Rica, PgBr 1 from Brazil, and PgMal 4 and PgMal 46 from Malawi, respectively), and lanes 8, 9, and 11 are Andean isolates (PgMal 30 and PgMal 38 from Malawi and PgWi 1 from the United States, respectively). Lanes 1 and 12 are the 1-kb ladder, and numbers on the left side indicate the fragment sizes of the 1-kb ladder. The arrows on the right side indicate the 690-bp Mesoamerican group-specific RAPD fragment and the 390-bp Andean group-specific RAPD fragment.

\section{$\begin{array}{lllllllllllllllll}1 & 2 & 3 & 4 & 5 & 6 & 7 & 8 & 9 & 10 & 11 & 12 & 13 & 14 & 15 & 16\end{array}$}

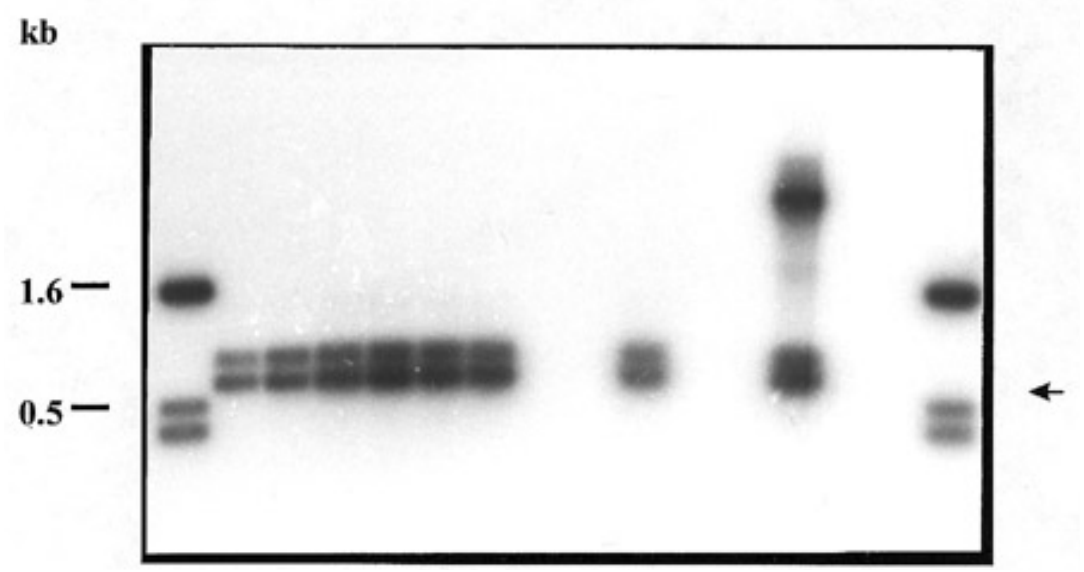

Fig. 2. Southern blot hybridization analysis of DNA fragments amplified by polymerase chain reaction (PCR) with the Mesoamerican group-specific primer pair from total genomic DNA of Phaeoisariopsis griseola isolates from five countries. A ${ }^{32} \mathrm{P}$-labeled recombinant plasmid containing the Mesoamerican group-specific random amplified polymorphic DNA (RAPD) fragment (pM3) was used as a probe. Lanes 2 through 7 and 10 are Mesoamerican isolates (PgAr 1 and PgAr 3 from Argentina, $\mathrm{PgCr} 1$ and $\mathrm{PgCr} 2$ from Costa Rica, PgBr 1 from Brazil, and PgMal 4 and PgMal 46 from Malawi, respectively), and lanes 8, 9, and 11 are Andean isolates (PgMal 30 and PgMal 38 from Malawi and PgWi 1 from the United States, respectively). Lane 12 is blank, lane 13 is a positive control (Mesoamerican RAPD fragment amplified from pM3), and lane 14 is a negative control (water). Lanes 1 and 16 are the 1-kb ladder, and numbers on the left side indicate the fragment sizes of the 1-kb ladder. The arrow on the right side indicates the 690-bp Mesoamerican group-specific RAPD fragment.

A sonication procedure was used to extract total genomic DNA from two types of P. griseola tissue: (i) mycelia (0.1 to 0.5 $\mathrm{mg}$ ) collected with a dissecting needle (carefully avoiding any agar) from 10-dayold colonies growing on V8 juice agar plates, and (ii) synnemata and conidia collected with a dissecting needle from individual sporulating lesions. In all cases, synnemata and conidia were collected from the lower surface of characteristic angular lesions on trifoliolate leaves and, in some cases, sporulation was induced by incubating leaves in small moist chambers (leaves were placed on small glass rods on the surface of moistened filter paper contained in a closed petri plate) for 24 to $48 \mathrm{~h}$ at room temperature.

Fungal tissues were placed in an Eppendorf tube containing $50 \mu \mathrm{l}$ of $10 \times \mathrm{PCR}$ buffer $(100 \mathrm{mM}$ Tris- $\mathrm{HCl}, \mathrm{pH} 9.0,500$ $\mathrm{mM} \mathrm{KCl}, 0.1 \%$ Triton) and $50 \mu \mathrm{l}$ of sterile distilled water. This suspension was sonicated with a Vibra Cell Model VC50 sonicator (Sonic \& Materials Inc., Danbury, CT) for a pulse of $2 \mathrm{~s}$ delivering $39 \mathrm{~W}$ at the probe tip. Tubes were centrifuged for $5 \mathrm{~s}$, and $10 \mu \mathrm{l}$ of this extract was used in the PCR.

RAPD analysis. For RAPD analysis, the OA11 ten-mer primer from Operon Technologies (Alameda, CA) Kit A was used as previously described (11). This primer was selected because it consistently directed the amplification of distinct polymorphic DNA fragments from $P$. griseola in a previous study (11). Fifteen $\mu \mathrm{l}$ of the RAPD reaction was analyzed by agarose gel electrophoresis in $1.0 \%$ agarose gels in $0.5 \times$ Tris-borate EDTA (TBE) buffer. Gels were stained with ethidium bromide, and DNA was visualized with a gel imaging system (Alpha Innotech Corporation, San Leandro, CA).

Cloning and Southern blot hybridization analysis. RAPD fragments were excised from agarose gels, and the DNA was recovered using silica matrix (Geneclean, BIO 101, Vista, CA). RAPD fragments were cloned with the TA cloning system (Invitrogen, San Diego, CA) according to manufacturer's instructions. Southern blot hybridization analysis was performed as previously described (10). Blots were hybridized with recombinant plasmid probes labeled with $\left[\alpha_{-}{ }^{32} \mathrm{P}\right] \mathrm{dCTP}$ by nick translation according to manufacturer's instructions (Gibco BRL, Gaithersburg, MD). Hybridizations were performed overnight at $37^{\circ} \mathrm{C}$ in a hybridization oven (model HB-1D, Techne Incorporated, Princeton, NJ). Membranes were washed three times at $42^{\circ} \mathrm{C}$ and exposed to X-ray film (Fuji, Japan) for $36 \mathrm{~h}$ at room temperature.

DNA sequence analysis. DNA sequences were determined using the dideoxynucleotide chain-termination method with Sequenase (USB, Cleveland, $\mathrm{OH}$ ) according to manufacturer's instructions. Sequences were assembled and compared 
using the software of the Genetics Computer Group of the University of Wisconsin (9).

PCR analysis. For PCR, final concentrations of the reagents utilized are indicated. Fifty microliter reactions were prepared by mixing $5 \mu \mathrm{l}$ of $10 \times$ buffer $(10 \mathrm{mM}$ Tris-HCl, $\mathrm{pH} 9.0,50 \mathrm{mM} \mathrm{KCl}, 0.01 \%$ Triton), $5 \mu \mathrm{l}$ of $\mathrm{MgCl}_{2}(2.5 \mathrm{mM}), 5 \mu \mathrm{l}$ of mixed dNTPs ( $0.2 \mathrm{mM}$ each), $0.3 \mu$ of Taq polymerase (1.5 U) (Perkin Elmer, Emeryville, CA), $0.5 \mu \mathrm{l}$ of each primer $(0.25$ $\mathrm{mM}$ ), and 2.5 or $5.0 \mu \mathrm{l}$ of the total fungal genomic DNA preparation ( 25 to $50 \mathrm{ng}$ ). For DNA extracts prepared from plant tissue or extracts prepared from fungal tissue by the sonication method, $50-\mu \mathrm{l}$ reactions were prepared by mixing $3 \mu \mathrm{l}$ of $\mathrm{MgCl}_{2}(1.5 \mathrm{mM}), 3 \mu \mathrm{l}$ of mixed dNTPs ( $0.12 \mathrm{mM}$ each), $0.3 \mu \mathrm{l}$ of $\mathrm{Taq}$ polymerase $(1.5 \mathrm{U}), 0.4 \mu \mathrm{l}$ of each primer $(0.4 \mathrm{mM})$, and $10 \mu \mathrm{l}$ of the undiluted or diluted (1:10) DNA extract. Initial PCR parameters were $94^{\circ} \mathrm{C}$ for $1 \mathrm{~min}$ (denature), $54^{\circ} \mathrm{C}$ for $90 \mathrm{~s}$ (annealing), and $72^{\circ} \mathrm{C}$ for $2 \mathrm{~min}$ (extension). However, to determine optimal PCR conditions for the group-specific primers and different $P$. griseola DNA extracts, a variety of parameters was tested.

\section{RESULTS}

RAPD analysis. RAPD analyses with primer OA11 were carried out with total genomic DNA from $P$. griseola isolates from Argentina (PgAr 1 and $\mathrm{PgAr} 3$ ), Costa Rica ( $\mathrm{PgCr} 1$ and $\mathrm{PgCr} 2$ ), Malawi (PgMal 4, PgMal 30, PgMal 38, and PgMal 46), the United States (PgWi 1), and Brazil ( $\mathrm{PgBr} 1)$. The Andean P. griseola RAPD pattern was generated for the previously characterized Andean isolates PgMal 30, PgMal 38, and PgWi 1; whereas the Mesoamerican pattern was generated for the previously characterized Mesoamerican isolates PgMal 4, PgMal 46, and $\mathrm{PgBr} 1$ (Fig. 1). Mesoamerican RAPD patterns were generated for the previously uncharacterized isolates from Costa Rica and Argentina, although the patterns generated for these isolates were not identical to those generated for Mesoamerican isolates from Malawi and Brazil. For example, each isolate from Argentina had a small (350 to $450 \mathrm{bp}$ ), less intensely stained RAPD fragment, whereas isolates from Costa Rica, Malawi, and Brazil did not.

Comparison of the Andean and Mesoamerican $P$. griseola RAPD patterns generated with primer OA11 revealed an approximately 400-bp RAPD fragment that was amplified from Andean but not from Mesoamerican isolates (Fig. 1). Here it is important to note that the small RAPD fragments amplified from the Mesoamerican isolates from Argentina were different in size compared with the intensely stained approximately 400-bp fragment characteristic of Andean P. griseola isolates (Fig. 1), suggesting that these are distinct RAPD fragments. Similarly, an approximately 700-bp RAPD fragment was identified that was amplified from Mesoamerican but not Andean isolates. Moreover, these putative group-specific RAPD fragments were detected in RAPD patterns generated with primer OA11 from all Andean and Mesoamerican isolates examined in this study and that of Guzmán et al. (11).

Cloning and Southern blot hybridization analysis of group-specific fragments. These putative Andean and Mesoamerican group-specific RAPD fragments were cloned from $P$. griseola isolates PgMal 38 and PgMal 4, respectively. Recombinant plasmids having the expected size insert were identified by digestion with the restriction enzyme EcoRI. Plasmids pA4 and pM3, which contain the approximately 400-bp Andean or 700-bp Mesoamerican RAPD fragment, respectively, were selected for further characterization. Southern blot hybridization analysis experiments in which pA4 was used as a probe and hybridized with the cloned Mesoamerican RAPD fragment from pM3 or vice versa revealed no hybridization between these fragments under conditions of low stringency. Southern blot hybridization experiments with $\mathrm{pA} 4$ as the probe revealed that the approximately 400-bp RAPD fragment was amplified from total genomic DNA of all Andean isolates examined (data not shown). Furthermore, the

\section{A \\ Mesoamerican \\ Andean}
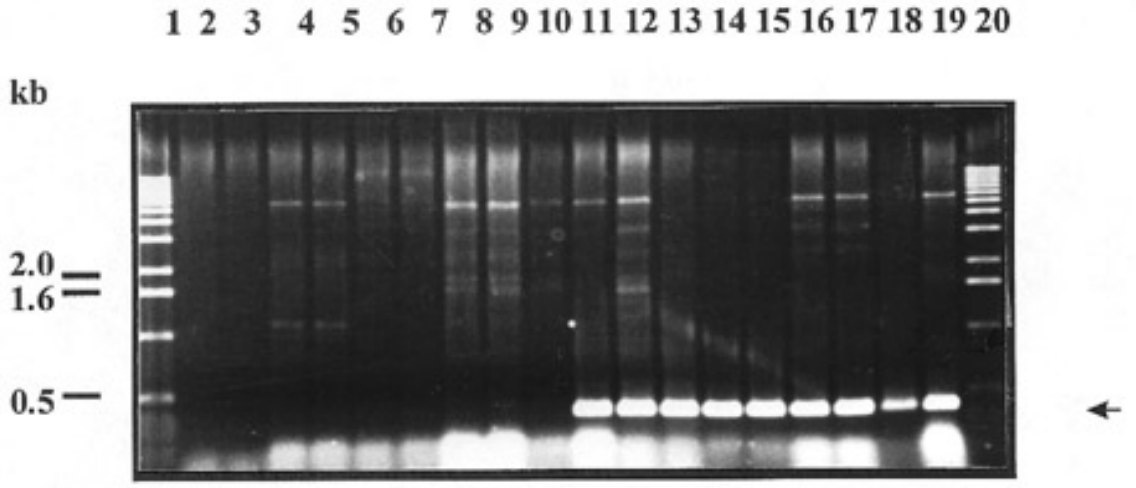

B

Mesoamerican Andean

$\begin{array}{llllllllll}1 & 2 & 3 & 4 & 5 & 6 & 7 & 8 & 91011 & 121314151617181920\end{array}$

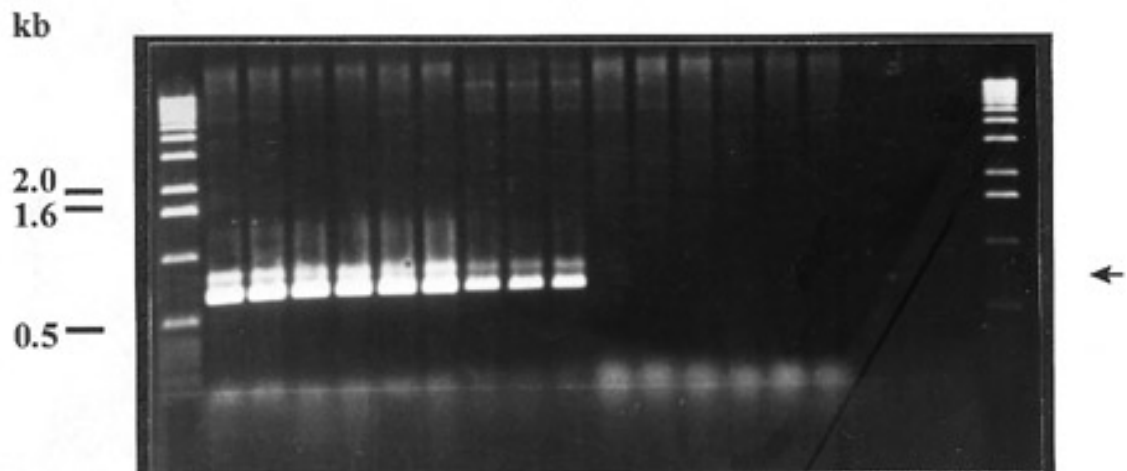

Fig. 3. Polymerase chain reaction (PCR) amplification of group-specific random amplified polymorphic DNA (RAPD) fragments from Phaeoisariopsis griseola with (A) the Andean group-specific primer pair or (B) the Mesoamerican group-specific primer pair. Lanes 2 through 10 are Mesoamerican isolates (PgMal 7 from Malawi and $\mathrm{PgBr} 4, \mathrm{PgBr} 5, \mathrm{PgBr} 6, \mathrm{PgBr} 7, \mathrm{PgBr} 10, \mathrm{PgBr} 11$, $\mathrm{PgBr} 12, \mathrm{PgBr} 13$, and $\mathrm{PgBr} 14$ from Brazil, respectively), and lanes 11 through 19 are Andean isolates (PgMal 1, PgMal 2, PgMal 3, PgMal 23, PgMal 24, PgMal 28, and PgMal 50 from Malawi and PgWi 2 and PgWi 3 from the United States, respectively). Lanes 1 and 20 are the 1-kb ladder, and numbers on the left side indicate the fragment sizes of the 1-kb ladder. The arrow on the right side of (A) indicates the 390-bp Andean group-specific RAPD fragment, and the arrow on the right side of (B) indicates the 690-bp Mesoamerican group-specific RAPD fragment. 
small RAPD fragments amplified from the Mesoamerican isolates from Argentina (Fig. 1) did not hybridize with the pA4 probe (data not shown), further demonstrating that these small fragments were distinct from the cloned 400-bp Andean RAPD fragment (data not shown). Similar experiments with $\mathrm{pM} 3$ as a probe revealed that two approximately 700-bp RAPD fragments were amplified from all Mesoamerican isolates examined (Fig. 2). cloned RAPD fragments in pA4 and pM3 do not share significant sequence similarity, and that they can be amplified from Andean and Mesoamerican P. griseola isolates from diverse geographical regions.

Sequence analysis and designing of group-specific primers. The complete nucleotide sequences of the cloned Andean determined from the recombinant plasmids RAPD fragment was $390 \mathrm{bp}$; whereas the Mesoamerican RAPD fragment was 690 bp. The sequences were $35 \%$ identical, which is consistent with the Southern blot hybridization results indicating no significant sequence similarity between these fragments. A blast search conducted with these RAPD sequences with the GenBank, EMBL, DDBJ, and PDB databases revealed no significant sequence similarity with other sequences.

$P$. griseola group-specific primer pairs were designed based on the nucleotide sequences of these cloned RAPD DNA fragments and primer OA11. The Andean group-specific primers were $20 \mathrm{bp}$ (Pa3093, 5'-CAATCGCCGTACATGACTAA-3'; sequence in italics is from primer OA11) and 21 bp (Pa3185, 5'CCGTTACCTCTATATTCCCAA-3'; sequence in italics is from primer OA11); whereas the Mesoamerican group-specific primers were both 20 bp (Pm2981, Together, these results indicate that the and Mesoamerican RAPD fragments were pA4 and pM3, respectively. The Andean

5'-CAATCGCCGTTTACGAAGAT-3' and Pm2982, 5'-CAATCGCCGTCGATCGATGA-3'; sequences in italics are from primer OA11).

PCR with the group-specific primer pairs. The Andean primer pair directed the amplification of an approximately 400-bp DNA fragment from total genomic DNA of the Andean isolate, PgMal 38, and no fragment from total genomic DNA of the Mesoamerican isolate, PgMal 4. The Mesoamerican primer pair directed the amplification of two approximately 700-bp fragments from total genomic DNA of the Mesoamerican isolate, PgMal 4, but no DNA fragment from total genomic DNA of the Andean isolate, PgMal 38. Neither primer pair directed the amplification of DNA fragments from common bean total genomic DNA. The optimal PCR parameters determined for the Andean primer pair were: $94^{\circ} \mathrm{C}$ for $1 \mathrm{~min}$ (denature), $63^{\circ} \mathrm{C}$ for $1 \mathrm{~min}$ (annealing), and $72^{\circ} \mathrm{C}$ for $1 \mathrm{~min}$ (extension) for 40 cycles; whereas those for the Mesoamerican primer pair were: $94^{\circ} \mathrm{C}$ for $1 \mathrm{~min}, 62^{\circ} \mathrm{C}$ for $1 \mathrm{~min}$, and $72^{\circ} \mathrm{C}$ for $1 \mathrm{~min}$ for 30 cycles. Because of the different parameters established for these primer pairs, they could not be used together in a single reaction. However, the group-specific primer pairs did direct the amplification of their respective target DNA fragments from a mixture of total genomic DNA of Andean and Mesoamerican $P$. griseola isolates (data not shown).

Whether the group-specific primer pairs would direct the amplification of the target DNA fragments from total genomic DNA of other P. griseola isolates was evaluated next. The Andean primer pair directed the amplification of the approximately 400-bp DNA fragment from all 12 Andean isolates examined and no distinct fragment from the 16 Mesoamerican isolates examined (Fig. 3A). The Mesoamerican primer pair

\section{$\begin{array}{llllllllllllllllll}1 & 2 & 3 & 4 & 5 & 6 & 7 & 8 & 9 & 10 & 11 & 12 & 13 & 14 & 15 & 16 & 17 & 18\end{array}$}

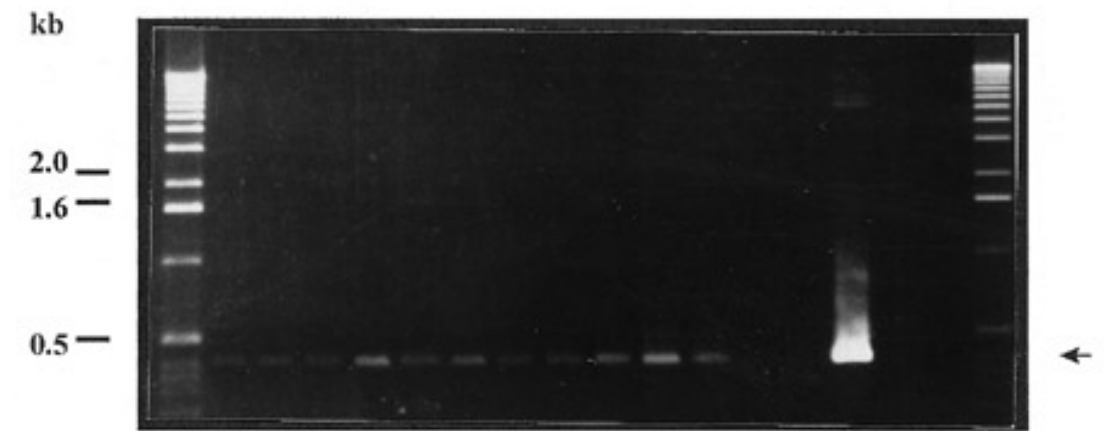

Fig. 4. Polymerase chain reaction (PCR) amplification of the Phaeoisariopsis griseola Andean random amplified polymorphic DNA (RAPD) fragment with the Andean group-specific primer pair. Synnemata and conidia were collected from 12 individual lesions from bean leaves inoculated with the Andean isolate, PgMal 38, and DNA was extracted by sonication. Lanes 2 through 13 represent the 12 individual lesions. Lane 14 is a blank, lane 15 is a positive control (Andean RAPD fragment amplified from pA4), and lane 16 is a negative control (water). Lanes 1 and 18 are the 1-kb ladder, and numbers on the left side indicate the fragment sizes of the 1-kb ladder. The arrow on the right side indicates the 390-bp Andean group-specific RAPD fragment. directed the amplification of the two approximately 700 -bp fragments from all 16 Mesoamerican isolates examined, including the isolates from Costa Rica and Argentina, and no fragment from the 12 Andean isolates examined (Fig. 3B). Southern blot hybridization analyses using pA4 or pM3 as probes confirmed that the approximately 400-bp and 700-bp fragments amplified from the Andean and Mesoamerican isolates, respectively, were homologous to the appropriate cloned RAPD fragments (data not shown). These results indicate that the Andean and Mesoamerican group-specific primer pairs can direct the amplification of this target DNA fragment from $P$. griseola isolates from diverse geographic regions, and further demonstrate that the Costa Rican and Argentinean isolates are Mesoamerican isolates.

PCR and the group-specific primer pairs were then evaluated for the detection $P$. griseola from infected leaf tissue. All attempts to amplify $P$. griseola DNA fragments from total genomic DNA extracted from individual lesions were unsuccessful. This was due to PCR inhibitors in these extracts, because the group-specific primer pairs did not direct the amplification of the appropriate RAPD fragment from $\mathrm{pA} 4$ or pM3 DNA added to the extracts. The group-specific primer pairs did direct the amplification of the appropriate RAPD fragment from $\mathrm{pA} 4$ or $\mathrm{pM} 3$ DNA added into total genomic DNA extracts prepared from uninfected tissue.

DNA was then extracted from fungal tissues of $P$. griseola with a sonication procedure. Two types of fungal tissue were tested: (i) mycelia obtained from fungal colonies growing on agar media, and (ii) synnemata and conidia collected directly from individual sporulating lesions on infected leaves. With extracts prepared from either mycelium or synnemata and conidia of the Andean isolate PgMal 38, the Andean primer pair directed the amplification of the approximately 400-bp DNA fragment (Fig. 4). Similarly, with extracts prepared from either mycelium or synnemata and conidia of the Mesoamerican isolate PgMal 4, the Mesoamerican primer pair directed the amplification of the two approximately 700-bp DNA fragments (data not shown).

To determine if PCR with the groupspecific primer pairs could be used to type $P$. griseola populations from diseased bean leaves, and to investigate whether selection pressure is exerted on $P$. griseola by the common bean gene pool, experiments were conducted in which bean plants representing the two gene pools were individually inoculated with an Andean or Mesoamerican $P$. griseola isolate, or with a mixture of both isolates. When Andean or Mesoamerican bean genotypes were inoculated with the Andean isolate only, Andean group $P$. griseola was detected by PCR with the 
Andean primer pair from 11 of 12 lesions sampled (i.e., the approximately 400-bp fragment was amplified); whereas $P$. griseola was not detected from these lesions with the Mesoamerican primer pair (i.e., no DNA fragment was amplified) (Table 1). Similarly, when Andean or Mesoamerican bean genotypes were inoculated with the Mesoamerican isolate, Mesoamerican group $P$. griseola was detected by PCR with the Mesoamerican primer pair from nearly every lesion sampled (i.e., the approximately 700 -bp fragments were amplified); whereas $P$. griseola was not detected from these lesions with the Andean primer pair. Similar results were obtained with the two Andean and Mesoamerican genotypes and with DNA extracts from mycelium or synnemata and conidia. These results established that the Andean and Mesoamerican primer pairs could be used to specifically detect Andean and Mesoamerican $P$. griseola from individual lesions, respectively, and that DNA extracts from either mycelium or synnemata and conidia could be used as templates for the PCR.

When the two Andean bean genotypes were inoculated with mixed inoculum of the Andean and Mesoamerican isolates, more lesions were found to be induced by the Andean than the Mesoamerican isolate on both genotypes and vice versa (Table 1). Interestingly, both isolates were detected from some individual lesions, suggesting mixed infections in these lesions.

\section{DISCUSSION}

In this study, group-specific PCR primers and a rapid DNA extraction method were developed for the detection and differentiation of the ALS pathogen, $P$. griseola. It was previously demonstrated that primer OA11 generated RAPD patterns that could differentiate the two $P$. griseola groups (11). In the present study, $P$. griseola isolates from Argentina and Costa Rica were identified as Mesoamerican isolates based on RAPD analysis with primer OA11. This finding is consistent with previous results on $P$. griseola-common bean coevolution in that Mesoamerican bean genotypes tend to be more commonly cultivated in Central America and Northern Argentina (20).

One approach to develop group-specific primers for $P$. griseola was to utilize RAPD fragments amplified with primer OA11. Putative group-specific RAPD fragments were cloned, and Southern blot hybridization and DNA sequence analysis revealed no significant sequence similarity between these fragments, indicating they were amplified from different regions of the fungal genome or from a homologous but highly divergent region. $P$. griseola group-specific primer pairs were then designed with sequences from the cloned RAPD fragments and primer OA11. Primer OA11 sequences were included in these primers to assure that the DNA frag- ments amplified from Andean (390 bp) and Mesoamerican (690 bp) P. griseola isolates would be sufficiently different in size to allow differentiation of the two $P$. griseola groups on the basis of fragment size as determined by agarose gel electrophoresis. These group-specific primer pairs directed the amplification of the target DNA fragments from Andean and Mesoamerican $P$. griseola isolates from bean-growing areas in five countries, indicating that these sequences are conserved in the fungal genome and that these primer pairs can be used to type isolates from a diversity of geographical regions. A drawback with this method is that the optimal PCR conditions for the primer pairs are not identical, so two PCR reactions must be performed for each isolate being examined.

One problem with using RAPD analysis (e.g., with primer OA11) to type $P$. griseola isolates is growing the fungus in culture and preparing total genomic DNA as a template for PCR. This is time-consuming (P. griseola is a slow-growing fungus) and labor-intensive (involving phenol-chloroform extraction), which limits the number of isolates that can be examined at a given time. Attempts to circumvent this by using the group-specific primer pairs and DNA extracts prepared from infected bean leaves were unsuccessful. This was probably due to PCR inhibitors because extracts from infected tissues (i) were brown in color, suggesting the presence of phenolic compounds, and (ii) the group-specific primer pairs did not amplify the RAPD fragments from plasmid DNAs added into these extracts. In contrast, extracts prepared from uninfected bean tissues showed no brown color, and the appropriate RAPD fragments were readily amplified from plasmid DNAs added to these extracts. Pigmented phenolic compounds have been reported to inhibit PCR amplification from infected banana tissues (14), and the inability to detect Magnaporthe poae from infected turfgrass roots by PCR was attributed to inhibitors in DNA extracts (3).

The sonication procedure developed in this study generated genomic DNA from fungal mycelium and from synnemata and conidia that was free of PCR inhibitors. Sonication is a rapid and efficient method for releasing DNA from these fungal tissues and requires only approximately 1 min per sample. This significantly reduces the time required for typing $P$. griseola isolates. Moreover, because this procedure worked with synnemata and conidia collected from leaf lesions, it is not necessary to grow the fungus in culture (a 10-day step). The relatively few cases in which the appropriate $P$. griseola DNA fragment was not amplified from extracts prepared by sonication were likely due to the small

Table 1. Detection and typing of Phaeoisariopsis griseola from angular leaf spot lesions by polymerase chain reaction (PCR)-mediated amplification of group-specific DNA fragments from extracts prepared from mycelium or synnemata and conidia

\begin{tabular}{|c|c|c|c|c|c|}
\hline Bean gene pool ${ }^{\mathrm{a}}$ & $\begin{array}{c}\text { Group } \\
\text { designation } \\
\text { of isolate }\end{array}$ & Primer pair & $\begin{array}{l}\text { Source of } \\
\text { DNA }\end{array}$ & $\begin{array}{c}\text { No. of } \\
\text { experiments }\end{array}$ & $\begin{array}{c}\text { PCR }^{\mathrm{b}} \text { positive } \\
\text { lesions/total } \\
\text { sampled }\end{array}$ \\
\hline \multirow[t]{12}{*}{ Andean } & \multirow[t]{4}{*}{ Andean } & \multirow[t]{2}{*}{ Andean } & Mycelia & 5 & $28 / 30$ \\
\hline & & & Synnemata & 4 & $20 / 20$ \\
\hline & & \multirow[t]{2}{*}{ Mesoamerican } & Mycelia & 5 & $0 / 30$ \\
\hline & & & Synnemata & 4 & $0 / 20$ \\
\hline & \multirow[t]{4}{*}{ Mesoamerican } & \multirow[t]{2}{*}{ Andean } & Mycelia & 4 & $0 / 26$ \\
\hline & & & Synnemata & 4 & $0 / 22$ \\
\hline & & \multirow[t]{2}{*}{ Mesoamerican } & Mycelia & 4 & $22 / 26$ \\
\hline & & & Synnemata & 4 & $18 / 22$ \\
\hline & \multirow[t]{4}{*}{ Mixed $^{\mathrm{c}}$} & Andean & Mycelia & 3 & $14 / 20^{d}$ \\
\hline & & Mesoamerican & Mycelia & 3 & $10 / 20^{\mathrm{d}}$ \\
\hline & & Andean & Synnemata & 3 & $14 / 20^{\mathrm{d}}$ \\
\hline & & Mesoamerican & Synnemata & 3 & $10 / 20^{\mathrm{d}}$ \\
\hline \multirow[t]{12}{*}{ Mesoamerican } & \multirow[t]{4}{*}{ Andean } & \multirow[t]{2}{*}{ Andean } & Mycelia & 3 & $30 / 30$ \\
\hline & & & Synnemata & 3 & $30 / 30$ \\
\hline & & \multirow[t]{2}{*}{ Mesoamerican } & Mycelia & 3 & $0 / 30$ \\
\hline & & & Synnemata & 3 & $0 / 30$ \\
\hline & \multirow[t]{4}{*}{ Mesoamerican } & \multirow[t]{2}{*}{ Andean } & Mycelia & 3 & $0 / 25$ \\
\hline & & & Synnemata & 3 & $0 / 25$ \\
\hline & & \multirow[t]{2}{*}{ Mesoamerican } & Mycelia & 3 & $25 / 25$ \\
\hline & & & Synnemata & 3 & $23 / 25$ \\
\hline & \multirow[t]{4}{*}{ Mixed } & Andean & Mycelia & 3 & $11 / 20^{\mathrm{d}}$ \\
\hline & & Mesoamerican & Mycelia & 3 & $14 / 20^{\mathrm{d}}$ \\
\hline & & Andean & Synnemata & 3 & $9 / 20^{d}$ \\
\hline & & Mesoamerican & Synnemata & 3 & $15 / 20^{\mathrm{d}}$ \\
\hline
\end{tabular}

a Bean genotypes were: Andean, cv. Topcrop and Malawian line 12-4; Mesoamerican, cv. Sutter Pink and Malawian line Namajengo. Because similar results were obtained for the two genotypes from each gene pool, the results for the two genotypes from each gene pool have been combined.

${ }^{b}$ Results are shown as number of positive detections (i.e., amplification of the expected DNA fragment)/total lesions tested.

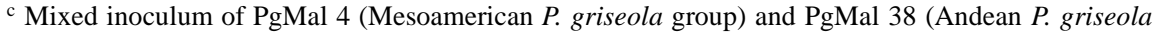
group) consisted of $1.2 \times 10^{4}$ conidia per $\mathrm{ml}$ for each isolate.

d Both Andean and Mesoamerican P. griseola were detected from some individual lesions. 
amount of fungal tissue used or the failure to release DNA from the fungal tissue. Similar problems have been reported for other methods used to prepare DNA extracts from fungal tissues $(12,13,15)$. In the case of $P$. griseola, this could be solved by increasing the number of PCR cycles, increasing the amount of fungal mycelium used, or by using synnemata and conidia collected from more than one lesion.

Experiments with $P$. griseola-infected plants demonstrated the reliability of this PCR technique for the specific detection of the two $P$. griseola groups. For example, with the Andean primer pair, the Andean $P$. griseola isolate was detected from nearly all leaf lesions on Andean or Mesoamerican genotypes inoculated with this isolate; whereas no false positives were obtained with lesions on plants inoculated with the Mesoamerican isolate. Similar results were obtained with the Mesoamerican primer pair. These results indicate that this method can be used to rapidly type $P$. griseola populations from the field.

The PCR detection and typing of $P$. griseola from ALS lesions on Andean and Mesoamerican bean plants inoculated with mixed inoculum of Andean and Mesoamerican $P$. griseola isolates supported previous results indicating that $P$. griseola coevolved with its common bean host $(11,17)$. Thus, the Andean isolate was more commonly detected on the Andean genotype; whereas the Mesoamerican isolate was more commonly detected on the Mesoamerican genotype. These results support the concept that Andean $P$. griseola isolates are more pathogenic on Andean genotypes; whereas Mesoamerican $P$. griseola isolates are more pathogenic on Mesoamerican genotypes. However, these results also demonstrate that this coevolution is not absolute because the Andean $P$. griseola isolate infected and caused ALS disease on the Mesoamerican genotypes, and the Mesoamerican isolate caused disease on the Andean genotypes. The detection of both Andean and Mesoamerican isolates from individual lesions suggests that some lesions may result from the combined action of multiple conidia, and that isolates of the two $P$. griseola groups can coexist on or in infected leaves.

This $P$. griseola PCR detection method now can be used to survey $P$. griseola populations in bean-growing areas, and the information from such surveys can be used to better identify an appropriate source(s) of ALS resistance for these regions. This PCR detection approach also could be useful for detection and typing of other plant pathogenic fungi.

\section{ACKNOWLEDGMENTS}

This research was supported by the USAID Bean Cowpea Collaborative Research Support Program (CRSP), and by a fellowship from the Organization of American States (OAS) to P. Guzmán. We thank M. Salgado and M. Araya for providing bean leaves with ALS symptoms from Argentina and Costa Rica, respectively. We also thank M. L. Pinzón, M. H. Guzmán, and P. A. Guzmán for technical assistance with the greenhouse studies.

\section{LITERATURE CITED}

1. Alvarez-Ayala, G., and Schwartz, H. F. 1979. Preliminary investigations of pathogenic variability expressed by Phaeoisariopsis griseola. Annu. Rep. Bean Improv. Coop. 22:86-87.

2. Audy, P., Laroche, A., Saindon, G., Huang, H. C., and Gilbertson, R. L. 1994. Detection of the bean common blight bacteria, Xanthomonas campestris pv. phaseoli and X.c. phaseoli var. fuscans, using the polymerase chain reaction. Phytopathology 84:1185-1192.

3. Bunting, T. E., Plumley, K. A., Clarke, B. B., and Hillman, B. I. 1996. Identification of Magnaporthe poae by PCR and examination of its relationship to other fungi by analysis of their nuclear rDNA ITS-1 regions. Phytopathology 86:398-404.

4. Cobb, B. D., and Clarkson, J. M. 1993. Detection of molecular variation in the insect pathogenic fungus Metarhizium using RAPDPCR. FEMS Microbiol. Lett. 112:319-324.

5. Cole, H. 1966. Angular leafspot associated with severe defoliation of red kidney beans (Phaseolus vulgaris L.). Plant Dis. Rep. 50:494.

6. Correa-Victoria, F. J. 1988. Pathogenic variation, production of toxin metabolites and isozyme analysis in Phaeoisariopsis griseola (Sacc.) Ferr. Ph.D. thesis. Michigan State University, East Lansing.

7. Correa-Victoria, F. J., Pastor-Corrales, M. A., and Saettler, A. W. 1989. Angular leaf spot. Pages 59-75 in: Bean Production Problems in the Tropics. H. F. Schwartz and M. A. PastorCorrales, eds. Centro Internacional de Agricultura Tropical, Cali, Colombia.

8. Crowhurst, R. N., Hawthorne, B. T., Rikkerink, E. H. A., and Templeton, M. D. 1991. Differentiation of Fusarium solani f. sp. $\mathrm{cu}$ curbitae races 1 and 2 by random amplification of polymorphic DNA. Curr. Genet. 20:391-396.

9. Devereux, J., Haeberli, P., and Smithies, O. 1984. A comprehensive set of sequence analysis programs for the VAX. Nucleic Acids Res. 12:387-395.

10. Gilbertson, R. L., Maxwell, D. P., Hagedorn, D. J., and Leong, S. A. 1989. Development and application of a plasmid DNA probe for detection of bacteria causing common bacterial blight of bean. Phytopathology 79:518-525.

11. Guzmán, P., Gilbertson, R. L., Nodari, R., Johnson, W. C., Temple, S. R., Mandala, D.,
Mkandawire, A. B. C., and Gepts, P. 1995 Characterization of variability in the fungus Phaeoisariopsis griseola suggests coevolution with the common bean (Phaseolus vulgaris). Phytopathology 85:600-607.

12. Henson, J. M., and French, R. 1993. The polymerase chain reaction and plant disease diagnosis. Annu. Rev. Phytopathol. 31:81109.

13. Henson, J. M., Goins, T., Grey, W., Mathre, D. E., and Elliot, M. L. 1993. Use of polymerase chain reaction to detect Gaeumannomyces graminis DNA in plants grown in artificially and naturally infested soil. Phytopathology 83:283-287.

14. Johanson, A., and Jeger, M. J. 1993. Use of PCR for detection of Mycosphaerella fijiensis and M. musicola, the causal agents of Sigatoka leaf spots in banana and plantain. Mycol. Res. 97:670-674.

15. Lovic, B. R., Valadez, V. A., Martyn, R. D., and Miller, M. E. 1995. Detection and identification of Monosporascus spp. with genusspecific PCR primers and nonradioactive hybridization probes. Plant Dis. 79:1169-1175.

16. Mzuku, W. A. B., Saka, V. W., Mbalule, J. C., and Kamwanba, S. 1990. Evaluation of bean (Phaseolus vulgaris) germplasm against angular leaf spot and some root knot nematode (Meloidogyne) species in Malawi. Zimbabwe J. Agric. Res. 28:15-21.

17. Pastor-Corrales, M. A., and Jara, C. E. 1995. La evolución de Phaeoisariopsis griseola con el fríjol común en América Latina. Fitopatol. Colomb. 19:15-24.

18. Schesser, K., Luder, A., and Henson, J. M. 1991. Use of polymerase chain reaction to detect the take-all fungus, Gaeumannomyces graminis in infected wheat plants. Appl. Environ. Microbiol. 57:553-556.

19. Schwartz, H. F., Correa V., F., Pineda D., P. A., Otoya, M. M., and Katherman, M. J. 1981 Dry bean yield losses caused by Ascochyta, angular, and white leaf spots in Colombia. Plant Dis. 65:494-496.

20. Seattler, A. W., and Correa-Victoria, F. J. 1983. Angular leaf spot in seed fields of Michigan red kidney beans. Mich. Dry Bean Dig. 8:2-3.

21. Singh, S., Gepts, P., and Debouck, D. G. 1991. Races of common bean (Phaseolus vulgaris Fabaceae). Econ. Bot. 45:379-396.

22. Trutmann, P., and Pyndji, M. M. 1994. Partial replacement of local common bean mixtures by high yielding angular leaf spot resistant varieties to conserve local genetic diversity while increasing yield. Ann. Appl. Biol. 125:45-52.

23. Welsh, J., and McClellan, M. 1990. Fingerprinting genomes with arbitrary primers. $\mathrm{Nu}$ cleic Acids Res. 18:7213-7218.

24. Wetzel, W. C., Dernoeden, P. H., and Millner, P. D. 1996. Identification of darkly pigmented fungi associated with turfgrass roots by mycelial characteristics and RAPD-PCR. Phytopathology 80:359-364.

25. Williams, J. G. K., Kubelik, A. R., Livak, K. J., Rafalski, J. A., and Tingey, S. V. 1990. DNA polymorphism amplified by arbitrary primers are useful as genetic markers. Nucleic Acids Res. 18:6531-6535. 